\title{
Study on Internationalization Strategy of China's New Business Education in the Background of Digital Economy
}

\author{
Jia Xie ${ }^{1} \&$ Tianshuo Zhang ${ }^{2}$ \\ ${ }^{1}$ Faculty of Education, Beijing Normal University, Beijing, China \\ ${ }^{2}$ BNU Business School, Beijing Normal University, Beijing, China \\ Correspondence: Tianshuo Zhang, BNU Business School, Beijing Normal University, Beijing 100859, China.
}

Received: May 12, 2021

doi:10.5539/ies.v14n10p95
Accepted: June 29, 2021

Online Published: September 26, 2021

URL: https://doi.org/10.5539/ies.v14n10p95

\begin{abstract}
As the global economy is undergoing transformation and upgrading in the background of the digital economy, it leads to a reformation of business education in the new context, which brings the concept of new business education in China. One of the significant features of the new business education is multidisciplinary teaching and learning. Meanwhile, it is closely related to strategic decision-making in disciplinary program design, research design, faculty recruitment, teaching models, and international strategies. Benefited from the internationalization of higher education in past years, traditional business education has gained an advantage in introducing international students, teachers, and resources and building global cooperation platforms, including international visits and multiple studies in an international context. However, it cannot meet the demand for cultivating talents in the era of the digital economy. This paper starts with the connotation and feature of new business education, discussing internationalization strategy with a fresh perspective and unique positioning. Meanwhile, it aims to provide a theoretical and practical value for China's business schools with internationalization strategy making in the background of the digital economy.
\end{abstract}

Keywords: digital economy, new business education, higher education, internationalization strategy

\section{Introduction}

\subsection{Transformation of World Business Context}

Nowadays, the world has entered the stage of regular pandemic prevention. China faces a slowdown in economic growth, upgrading of industrial structure, and a competitive environment under volatile international and domestic situations. In the post-epidemic era, the digital economy has become a new growth and driving force for global economic development. In response to this change, the Chinese government has initiated a new approach to business education. The internationalization of business education is one of the approaches. Since the 1980s, people have gained a high degree of recognition towards the internationalization strategy of traditional business education. Based on the practice over the years, formal business education remained relatively high in internationalization strategy making, course teaching, and scientific research. However, with an increasing proportion of the digital economy in China's GDP, the building and upgrading of digitization among companies, and the diverse global environment for talent cultivation and competition, the connotation of new business education is further expanded. The internationalization strategy of traditional business education can no longer meet the needs for talent cultivation under the new form of economy. Therefore, transformation and an upgrade are required.

As one of the most featured social and economic backgrounds in the new era, the digital economy brings the re-construction of business disciplines among business schools worldwide. Based on a review of the digital economy development strategies among developed countries in the world (Table 1), it can find that the strategic layout and practices of the digital economy in these countries, such as European countries and the United States, began at the beginning of the 21 st century, earlier than China. 
Table 1. Part of digital economy strategies of major developed countries in the world

\begin{tabular}{|c|c|c|c|c|}
\hline $\begin{array}{l}\text { Category } \\
\text { Country }\end{array}$ & $\begin{array}{l}\text { Digital economy } \\
\text { Top-level design }\end{array}$ & Digital industry & New infrastructure & Digital innovation \\
\hline $\begin{array}{l}\text { United } \\
\text { States }\end{array}$ & $\begin{array}{l}\text { Information Superhighway } \\
\qquad(1990)\end{array}$ & $\begin{array}{l}\text { U.S. Open Data Action } \\
\text { Plan (2014) }\end{array}$ & $\begin{array}{c}\text { National Broadband Research } \\
\text { Agenda (2017) }\end{array}$ & $\begin{array}{l}\text { Starting the big data research } \\
\text { and development plan (2012) }\end{array}$ \\
\hline $\begin{array}{l}\text { United } \\
\text { Kingdom }\end{array}$ & Digital Britain (2009) & & $\begin{array}{l}\text { The broadband coverage rate } \\
\text { of } 2 \mathrm{Mbps} \text { reached } 100 \% \text {. } \\
\text { (2015) }\end{array}$ & \\
\hline $\begin{array}{l}\text { European } \\
\text { Union }\end{array}$ & $\begin{array}{l}\text { European Digital Agenda, } \\
\text { Digital Europe Plan (2014) }\end{array}$ & $\begin{array}{l}\text { The digital single } \\
\text { market strategy. (2015) }\end{array}$ & $\begin{array}{l}\text { Digital transformation in } \\
\text { fields of healthcare. }\end{array}$ & $\begin{array}{l}\text { Human Brain Project to } \\
\text { explore the field of artificial } \\
\text { intelligence }(2013)\end{array}$ \\
\hline Germany & $\begin{array}{l}\text { Digital Germany } 2015 \\
\qquad(2010) \\
\text { the Industry } 4.0 \text { plan } \\
\text { (2013) }\end{array}$ & $\begin{array}{l}\text { Digital Strategy } 2025 \\
\qquad(2016.03)\end{array}$ & $\begin{array}{l}\text { Digital Agenda to build a } \\
\text { nationwide high-speed } \\
\text { broadband network (2018) }\end{array}$ & \\
\hline Japan & $\begin{array}{l}\text { E-Japan strategy } \\
2013(2001)\end{array}$ & & & $\begin{array}{l}\text { Science and Technology } \\
\text { Innovation Comprehensive } \\
\text { Strategy (2013) }\end{array}$ \\
\hline Korea & $\begin{array}{l}\text { IT2000: Vision of Wisdom } \\
\text { Island } \\
(1991)\end{array}$ & $\begin{array}{c}\text { The manufacturing } \\
\text { innovation } 3.0 \text { strategy. } \\
\text { (2014) }\end{array}$ & $\begin{array}{l}\text { 5G and artificial intelligence } \\
\qquad(2014)\end{array}$ & \\
\hline Singapore & $\begin{array}{c}\text { National Computerization } \\
\text { Plan, National I.T. Plan, etc. } \\
\text { (1981) }\end{array}$ & & Smart Nation Plan (2014) & \\
\hline
\end{tabular}

Klaus Schwab, chairman of the World Economic Forum, emphasized the transformative power in the Fourth Industrial Revolution book. He thinks that there are three major trends in the world economy. The first trend is the general trend, which means technology and digitization is changing everything. The speed, scope, and depth of the Fourth Industrial Revolution are unprecedented. The second trend is the great opportunity, which means the cross-border subject's integration of physics, mathematics, biology, and a series of emerging technological breakthroughs such as artificial intelligence and robotics. The third trend is the enormous challenge, which means the emergence of new business models, the overturn of existing business models, and reshaping production, consumption, transportation, and delivery systems. This transformation is revolutionary rather than reformative.

$\mathrm{Wu}$ (2018) pointed out that the key to improving the quality of talent cultivating for higher education is to grasp the new trends of the new era. The construction of new business education should be directed at serving the market economy and emphasize the close integration of subject education and serving the needs of the market economy. In this way, the new business education can cope with technology, society, and the economy. McKinsey, a world-renowned consulting company, published a report in 2011. The report mentioned that the big data era has arrived. Also, data has infiltrated every industry and business sector, becoming an important production factor. Data analysis and application indicate the arrival of new productivity growth and consumer surplus. Therefore, new business education should have the following features.

Based on the China Academy of Information and Communications Technology data, United States ranks first in terms of digital economy scale globally in 2018, reaching 12.34 trillion U.S. dollars. China reached 4.73 trillion U.S. dollars, ranking second. The digital economy scale of Germany, France, the United Kingdom, and Japan exceed 1 trillion yuan, respectively. After data collecting, it turns out that the proportion of the digital economy in each economy is positively associated with their overall scale of GDP. The digital economy of the United States, Germany, and the United Kingdom accounts for more than $60 \%$ of GDP.

In comparison, the percentage for Japan and South Korea is more than $40 \%$, and the ratio for Singapore and China is more than $30 \%$. The digital economy has become the core driving force of social and economic development in the new era. Its layout of major developed countries in the world is earlier than that of China. 
Furthermore, while we look into the business education in the above countries, it becomes a common phenomenon that occurrence and transformations of digital-related education in higher education associates with the development of the digital economy in those countries, and business education is one of the critical areas that transform. Among all the strategies, internationalization is an essential strategy for helping business education service the context. Therefore, it is necessary to study how to improve business education from internationalization strategy through the methodology of international comparison.

\subsection{Current Business Education in China}

Business education was one of the significant subjects of modern higher education discipline since it launched in China. It became an independent discipline, equally with liberal arts, sciences, engineering, agriculture, medicine, and art. According to China's General College Undergraduate Majors Catalog 2012, social sciences covers economics, management, philosophy, law, education, literature, history, art, and other disciplines. Traditional business studies belong to liberal arts. Since the reform and opening up, business education has become a diverse discipline with large-scale and different training levels in China, with business degree-granting increasing year by year. In terms of training direction, China's business studies, in the broader sense, cover majors of economics and business administration. In terms of training levels, it covers undergraduate programs, postgraduate programs, and doctoral programs. In terms of capacity, business education is second to engineering regarding the number of students. As the digital economy's emergence, including the internet, big data, cloud computing, and artificial intelligence, dramatically changes economic growth, which further gives birth to the emergence of new business education. In this study, we define business education as majors in Economics and Business Administration. New Business Education, therefore, refers to the transformation brought by the digital economy in majors of Economics and Business Administration.

According to recent years, the annual number of students studying business administration has reached 3 million, and those studying economics have reached nearly 1 million. The total number of graduated students is almost 4 million annually, accounting for nearly $1 / 3$ of students in other fields, such as humanities, social sciences, and science and engineering. The number of students who majored in economics and business administration increases year by year (Figure 1). More than 580 colleges and universities offer undergraduate programs majored in Economics and Business Administration in China by 2019, and 170 colleges and universities offer graduate programs. According to the plan of undergraduate programs for first-class universities, from 2019 to 2021, China plans to add more majors to first-class universities. Among these, a major in Economics and Business Administration ranks first, demonstrating the importance of business education to China's economic growth.
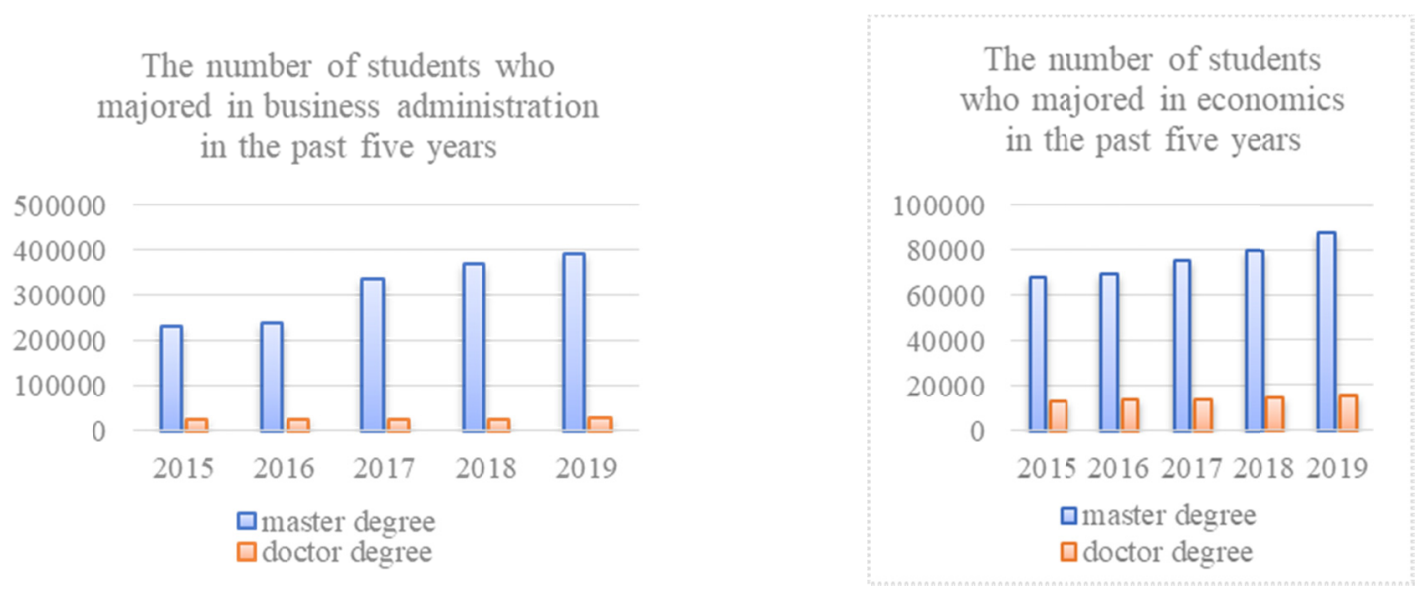

Figure 1. Number of students who majored in Economics and Business Administration in recent five years

\subsection{Chinese Government Attaches Great Importance to the Transformation of China's Economy and Reaction from Higher Education}

In corresponding to the transformation of the business environment, the Chinese government issued official guidance for higher education in 2018. It proposed the concepts of new engineering, new medical science, new agriculture, and new liberal arts based on the concept of new engineering. Under the new Liberal Arts, new 
business studies are the recombination and crossover of economics and business administration and elements of the digital economy in programs delivering. It aims to give students comprehensive interdisciplinary business education with new ideas, new models, new methods, and new technologies. The General Office of the Central Committee of the Communist Party of China and the General Office of the State Council issued the Implementation Plan for Accelerating the Promotion of Educational Modernization 2018-2022 in 2018. The plan proposed the Six Excellences and One Top-notch Plan 2.0 to promote higher education development. New liberal arts construction is one of them.

Through the official guidance, the internationalization strategy for the new business education plays a key role. It emphasizes the opening of education as an important strategic decision for building a powerful nation at the level of higher education. The National Medium and Long-term Educational Reform and Development Program 2010-2020 (http://www.moe.edu.cn/srcsite/A01/s7048/201007/t20100729_171904.html) gives clear instructions towards international exchanges and cooperation among universities. In addition, the Overall Plan for Promoting the Construction of World-Class Universities and First-Class Disciplines (http://www.gov.cn/zheng/content/2015-11/ 05/content_10269.htm) lists that promoting international exchanges and cooperation as one of the ten critical tasks. The internationalization of higher education is believed to be conducive to the construction of double first-class among universities.

\section{Methodology}

This paper examines research questions such as the appropriate international strategy for the New Business Education in China. How to define New Business Education in China? How the context changed through the occurrence of the digital economy in recent years. What can we learn from the experiences of the developed countries worldwide? In order to address these questions and have a thorough understanding of international strategy for the New Business Education, we use a comparison approach to verify the market share of the digital economy in major developed markets and how it affects business education in developed countries. China's New Business Education must learn from the international experience in aspects of how the spread of the digital economy changed business education in major developed countries. From a historical viewpoint, international strategy contributed actively to the growth of business schools in teaching, students, and faculty mobility. However, with the spread of the digital economy in recent years, especially after the pandemic situation from 2020, industries undergo a transformation and updating of digital upgrading rapidly, and ways of internationalization also undergo dramatic changes. There would be much international experience for China's Business Education to learn from in the new context.

\section{Internationalization Strategy Plays a Key Role in Helping Business Education Developing}

\subsection{Literature from International Scholars}

The internationalization of higher education has a long history. Knight (1994) proposed a systematic elaboration towards the internationalization of education. She points out that 'Internationalization of education is the process of integrating international dimension and cross-cultural concepts into the teaching, research, and service functions of educational institutions. Knight's definition of the internationalization of education begins with its process, providing a direction for the development of international dimensions and cross-cultural concepts. Van der Wende (1997) defines the internationalization of education from another perspective. He points out that the definition of internationalization of education should not be limited to educational institutions but should reflect the demands and challenges of the globalization of society, economy, and human resources. The internationalization of education should be systematic efforts to make higher education responsive to the requirements and challenges of globalization of society, economy, and labor market. Van der Wende (1997) defines the internationalization of education as a systematic concept, emphasizing the individuals who carry the internationalization of education and the role of institutions and systems in this process.

Zha (2003) considers internationalization as students, faculty, and administrative staff at home and abroad participate and benefit from values, beliefs, and insights of knowledge on an equal basis. Also, it covers the cultural exchange between all participants and combining localization and internationalization simultaneously. Echevin and Ray point out that the internationalization of higher education refers to the cross-border or cross-regional activities among universities in terms of staffing, teaching, enrollment, and learning resources. The internationalization of higher education is a strategy of higher education responsive to globalization, and it is also the inevitable result of globalization.

As globalization in the economy and education becomes a common phenomenon, it increasingly requires talents with proficient knowledge in the world economy, trade, production, and management. Regarding the value of internationalization of higher education, some scholars pointed out that the priority is that higher education 
should be open to the outside world, participate in international academic exchanges, strengthen international understanding and cooperation and promote world peace and development. Guillotin (2015) realized the importance of internationalization strategy and practices, including internationalization strategy-making. Freitas et al. (2016) suggest the combination between strategy and specific internationalization practices. Bradford et al. (2017) define internationalization as coordinating resources within universities and their strategic coordination. Also, many scholars have mentioned concrete measures to build international exchanges and cooperation platforms. Some scholars argue that the core standards of internationalization are the choice of international cooperation partners (Hujuk, 2015; McCormick \& Stephen, 2016), teaching, and curriculum internationalization (Hou \& Zou, 2016; Seno-Alday \& Budde-Sung, 2016).

\subsection{Literature from Chinese Scholars}

The understanding of the internationalization of education among Chinese scholars began in the same period. Gao (1994) pointed out that the vital aspect of the internationalization of business education is the educational concept, teaching content, and educational technology. Zheng (1997) mentioned that 'Internationalization of education is to conduct international exchanges in educational ideas, teaching models, courses, teaching materials, students. Gu (1998) pointed out in the Dictionary of Education that 'The development trends of education among countries are strengthening foreign language teaching, enhancing international exchanges of personnel and conducting international cooperation in education and academics. Both Zheng and Gu emphasized the role of international exchanges in the internationalization of education and explained the specific measures of international exchanges. Wang (2002) mentioned in The Scientific Connotation of Internationalization of Higher Education that the internationalization of higher education is an objective requirement of economic and social development. The internationalization of higher education does not mean to be fully in line with international standards; the goal is to realize the shared ideals of human society better and protect the interests of one's own country and nation. Chen (2002) further defined the internationalization of higher education in specific activities like the ability to conduct international exchanges among teachers and students and the campus cultural atmosphere. Liu et al. (2015) pointed out that the internationalization in business schools lies in the distribution of business schools, teaching ideas, teaching methods, and teacher resources.

Niu et al. (2017) pointed out that the key to the internationalization of business education is to have two-way communication and exchange. Zhu et al. (2017) cited the opinion of Marburger, former president of the State University of New York at Stony Brook, mentioned that once the discipline construction is in line with international consensus standards, the gap between China and the world's first-class disciplines is noticeable. Therefore, it needs to narrow the gap by developing disciplines. Niu et al. (2019) evaluated and compared the internationalization of China's business school to foreign counterparts from the five dimensions of strategy, teaching, scientific research, management, and staff. They pointed out that there is little difference in internationalization performance in terms of management and staff, and it is worth mentioning that China's business schools have better performance in scientific research than their counterparts. However, China's business schools have weaker performance in both strategy and teaching than their foreign counterparts.

\subsection{Discussion}

It reviewed that internationalization in business education includes professional training for talents and their attitude, awareness, activity capability, and knowledge. Based on previous literature, the internationalization of business education is one of the critical strategies for world-class universities and the necessary measures and strategic adjustments made by higher education to adapt to the context of economy and trade globalization and market demand. From a narrow perspective, the internationalization of higher education effectively promotes the depth and breadth of business knowledge dissemination, cultivates business talents to world-class standards, and dramatically enhances students' international awareness and international activity capabilities. From a broad perspective, the internationalization of higher education is an important driving force for enhancing international understanding and cooperation and promoting world peace and development. However, as Yao (2019) mentioned, the internationalization of higher education is a phenomenon in which elements related to it are dynamically adjusted with the continuous development of society. It, therefore, is a phenomenon influenced by people, history, inclusiveness, diversity of society, institutes.

\section{Occurrence of New Business Education}

New business education emerges with the context of the transformation and upgrade of the overall economy. In other words, technologies such as the internet, big data, and artificial intelligence are changing people's lifestyles and business models. It requires traditional business teaching to integrate with subjects such as artificial intelligence, big data. As the growth of our economy is closely connected with digital, technology, software 
engineering, it calls for the change of talents cultivation. Talents are called to familiar with knowledge of various disciplines, having the ability to sense and grasp business opportunities and equip with interdisciplinary knowledge and necessary skills. Otherwise, the understanding of the overall context only remains on the surface and cannot be deepened.

Traditional business education often focuses on western economic theory and western case teaching, emphasizing economic theory. It is rarely linked to the local business phenomenon. New business education would focus on China's economy, taking Chinese cases as a case study to provide China's solutions for the world economy. It would use Chinese theories to explain China's phenomenon, solve Chinese problems and guide China's economic development. However, it is necessary to know that there is no contradiction between focusing on China's facts and the internationalization of new business education. On the contrary, building Chinese theory in the global environment requires absorbing cutting-edge educational concepts and drawing on practical experience from the world. In this way, it can better prevent possible risks in the process of new business education construction.

With further adjustment of social and economic transformation and upgrading, business schools must update the traditional teaching model because they directly serve the needs for economic growth. Business schools need to work closely with enterprises and companies, aiming to cultivate more talents with the right skills and capabilities in the business world. The core element of talent cultivating is integrating the talent resources among universities, enterprises, and research institutes to achieve the effects of resource agglomeration. However, in the current practice of talent cultivating, enterprises and universities have fewer opportunities to work together for resources and complement integration. Furthermore, there is often a considerable gap between talents in the college and talents requested from a business, which is also the problem that new business education needs to address. With the development of the digital economy, the government needs to play the role of strategic design further, revitalize neglected resources from industries, universities, and other parties, collect data and empower universities. In this way, it can promote the talent cultivation level of new business education to meet the demand from the business world.

\section{Internationalization Strategy in New Business Education}

Xi Jinping pointed out that socialism with Chinese characteristics has entered a new era in terms of instructions of talent cultivation. China is building a modern socialist country based on a moderately prosperous society and poverty elimination. Therefore, there is an urgent need to cultivate many high-level talents with both ability and political integrity. Xi Jinping emphasized the critical role of higher education in cultivating innovative talents, serving economic and social development, and promoting the modernization of the national governance system and governance capabilities. Nowadays, China's economy has entered the era of the digital economy. The further transformation and upgrading of the economic structure require a response from business education. The development of the era requires innovation in business ideas and talent cultivation with higher quality for the new economic form, and internationalization strategy is among the essential strategies.

In February 2019, the Central Committee of the Communist Party of China and the State Council issued the China Education Modernization 2035, which lists ten strategic tasks for education modernization. Developing a new pattern of education opening up is one of the ten strategic tasks and a significant move for China's education system to implement the innovation-driven development strategy, cultivate first-class talents with international competitiveness, and serve China's economic development.

From the national economic perspective, a series of new technologies such as big data, artificial intelligence, machine manufacturing, and blockchain have brought about the integration and crossover of cyberspace, physical space, and physical space. The world is becoming smaller and the ties between countries, especially economic and trade ties, get more strengthened - these updates in the business world challenge what and how to deliver knowledge in business schools. For example, the digital economy breaks through the geographic barrier for production and consumption. Big data and the internet allow simultaneous diffusion of technology and the sharing of information, which means knowledge should also be updated. An interconnected platform for communication and interaction is also needed to break the boundaries between disciplines, schools, and countries.

In terms of the nature of the university itself, talent cultivating can regard as the development and change of the business form as the benchmark for talent training. Also, the university should strengthen the link between talent cultivating and business practices. It would be valuable to be guided by the business environment and improve the ability of teachers and students to solve business problems.

In terms of the nature of the market, the commercial market is a complex, changeable and coexistent 
environment. Teachers and students need to strengthen their ability to find problems in the market. The relationship between universities and the commercial market should be strengthened, and the ability of university talents to solve practical problems should be enhanced.

From an international perspective, the digital economy construction in mainstream developed countries is earlier than that of China. Therefore, their new business education construction has accumulated more theoretical and practical experience. The internationalization strategy is a meaningful way to respond to China's new business education construction and improve its quality. The pragmatic formulation of a scientific internationalization strategy is of great significance to the construction of new business education, the development of China's business schools, and the enhancement of international competitiveness of business education in China.

\section{Internationalization Strategy is the Inevitable Choice of the New Business Education}

Based on related literature, the internationalization strategy is essential for constructing new business education. Czinkota et al. pointed out, "business education has always been at the forefront of internationalization in higher education disciplines because it is often regarded as an entity company, and can be further divided as an entity company that provides professional services." (Czinkota, Grossman, Javalgi, \& Nugent, 2009; Javalgi \& Grossman, 2014)

For example, the reasons that business education is at the forefront of the internationalization of education are the broad applicability of the business education knowledge and theory, the universal relevance of the business education environment, the flow of students, and multinational business courses. This study intends to suggest the following three aspects of internationalization strategies making for new business education.

\subsection{Expend the Map of the Traditional Internationalization Strategy, Deepen and Diversify Ways of} Internationalization in Business Education

Globalization offers great opportunities and challenges for business education. Traditionally, Chinese business school focuses more on the international exchange and cooperation with top universities in developed countries. However, as the digital economy is developing and the Chinese economy grows more closely with One Belt One Road countries, business schools need to explore international opportunities for students within the new business education era. Nevertheless, as the internationalization strategy of traditional business education orients western universities more, Chinese universities value those big names of western universities than tangible ways of exchange. In most cases, students and faculty involved in international exchange programs were short-term visits, including limited topics such as customs and cultural level, less academic knowledge, and fewer local students involved. Therefore, the interaction and communication are insufficient. Thus, establishing an international cooperation platform in the new era should pay more attention to a diversified exchange and more exchange in academic projects. Research collaborations also need to be included between universities. Among academic projects, we suggest to include digital economy, and those related topics as internet finance, artificial intelligence, future machine, and other frontier projects. Also, we need to explore more bilateral degree programs for students in digital-related areas. It will allow students to have a longer time to study professional knowledge and allow students to experience life and culture in an international environment.

In addition to expanding the internationalization map, the construction of new business education should also pay attention to exploring the resources of international non-profit organizations, offering internships or training opportunities for students. This will effectively help students build a multi-dimensional cultural vision and improve cross-cultural communication skills for students.

\subsection{New Business Education Consider Multinational Companies in the Internationalization Strategy Making}

Under the guidance of integration of business education and the corporate world, cultivating new business talents should strengthen contacts and enhance collaboration with enterprises, especially those multinational enterprises with high student employment rates. The new business education should cater to the needs of enterprises, adjust and update textbooks and cases teaching, add the latest industry knowledge, technical means, and the latest standards correctly.

New business education should break the barriers of school-enterprise cooperation in the traditional business education environment and strengthen the school-enterprise cooperation in related aspects. Faculty and lecturers are encouraged to get involved in business cases with colleagues from corporate. Schools and institutes also need to create opportunities for experts in the industry to give lectures to students. Moreover, business schools are encouraged to increase the curriculum proportion of practice and strengthen students' cultivation of practical ability.

Furthermore, new business education may also consider the following two aspects. First, customizing teaching 
according to the needs of enterprises, breaking the boundaries of disciplines, tailoring knowledge, skills, and quality education curriculum systems, and implementing differentiation teaching. Second, establishing a common information exchange platform, specialty construction platform, teacher training platform, student employment platform, employee training platform, and technology research and development platform between schools and enterprises. Meanwhile, business schools and enterprises could analyze and evaluate collaboration data together, identify skills required by the market timely, provide unique training for students based on data analysis.

\subsection{Develop an Online International Cooperation Platform and Work on the Concept of Cloud Business School}

The outbreak of the covid-19 changed international exchange and collaboration ways since 2020 - online course delivering has become a significant way of course delivery in the higher education field. The development of online courses further narrows the distance between countries, and the deepening of internationalization becomes much easier to operate. China's online education began in 2003 when the Ministry of Education launched Higher Education Quality and Teaching Reform Project and National Quality Course Construction Project among colleges and universities. The projects require that the proportion of multimedia class hours reach more than $30 \%$ for required courses among key universities while the remaining universities should reach more than $15 \%$. This is the beginning of information construction for Chinese universities. The construction of online education platforms has been keeping up with the international pace. From the Open Educational Resources (OER) proposed by UNESCO in 2002, and the OER represented by the Massachusetts Institute of Technology in the United States, and the MOOC platform that appeared in the United States in 2008, China was chasing pace with those big counterparts.

There is still a gap between Chinese universities and their counterparts for more than a decade of information construction in terms of the online education platform construction. The gap mainly lies in the business education field. China's online higher education courses focus more on engineering, science, and medicine. Humanities and social science courses account for a relatively high proportion. According to the statistics of China's early quality open courses and quality resource sharing courses, engineering courses accounted for the highest proportion (24\%), followed by science courses (10\%), medicine (9\%), and management $(6 \%)$.

In contrast, business courses account for the most significant proportion (22\%) among foreign MOOC platforms, followed by computer $(16 \%)$, data science $(10 \%)$, and social science $(10 \%)$. It concludes that China's online education resources for business education have a bigger room for international cooperation. Business education from developed countries started early, and the curriculum was much diversified. It is worth learning from their experience in constructing new business education for China's business school in the post-epidemic era.

Besides, online platforms of business education in developed countries include universities and include courses jointly developed by universities and enterprises. For example, the Edx platform has courses from Harvard University, Massachusetts Institute of Technology, and other universities and courses contributed by leading companies such as Microsoft, IBM, and Amazon. Among these, Microsoft provides 258 courses, ranked third among all participating parties. In addition, there are as many as 193 courses offered by schools-schools, schools-enterprise, or enterprise-enterprise alliances. Therefore, while building new business education, China's business schools should actively build and share online resources with international partner universities and build a resource-sharing platform with domestic and multinational enterprises. The online platform particularly needs enterprises and other social parties to participate and devote their advantages to make up for limited campus resources. China's business schools should also invite and encourage enterprises and other parties to participate in constructing online platforms, coordinate the online resources, and enhance its international influence.

6.4 The Use of Chinese Business Cases and the Development of Chinese Economic Theories Are the Keys to the Internationalization Strategy of New Business Education

In the context of education globalization and the digital economy, while further promoting the internationalization strategy, China's new business education should strengthen cooperation with UNESCO and participate in bilateral, multilateral, global, and regional educational cooperation. In particular, China should actively participate in the research and formulation of educational policies, rules, and standards with international organizations. China's opinion, Chinese business cases, and its economic development theory should be included. Chinese business schools are encouraged to work actively in academics and research to contribute Chinese wisdom and enhance its international influence and voice. The prerequisite for achieving the above goals is to improve the quality of China's new business education and enhance the levels of its global recognition. 


\section{Conclusion and the Future}

As an effective means of building soft power for a nation, the internationalization of education has been highly valued by governments, institutions of higher education, and social organizations in the world. The research report by the Center for Higher Education Internalization (CHEI), the International Association of Universities (IAU), and the European Association for International Education (EAIE) show that the internationalization of higher education has become the direction and the goal for many countries and institutions, including the United States.

In the era of the digital economy, relations between countries also change. Problems such as economic environment, economic crisis, climate change, ethnic and religious conflicts force the country leaders to realize that there is still a certain degree of threat. The internationalization of education plays a pivotal role in solving global crises and seizing global development opportunities. Among them, the degree of internationalization of business education significantly impacts the global economic and trade exchanges and the international business environment. The effective way to promote business education is to expand the exchange programs for faculty and researchers, expanding the internationalization map in the world, developing more long-term programs and activities, employing more online resources, and establishing more China case databases. Only through these ways will Chinese business education be able to widely absorb global talents, promote international understanding, and spread China's culture and value system to the rest of the world, enhancing multilateral understanding in the world. Furthermore, China can also learn from world-class universities in a diversified way, establish its international image scientifically and effectively, promote its international status and safeguard its national security.

Covid-19 hit the world in 2020, leading to stagnation of international exchanges and cooperation activities among countries with lots of uncertainty. However, with the regular global epidemic prevention, international exchanges and cooperation enter a period of reorganization and transformation. New business education becomes a subject at the forefront of internationalization. Therefore, Chinese business schools must insist on strengthening digital educational technology, innovating international cooperation platforms, and adhering to openness and cooperation. It is the obligation and responsibility of new business education in China to bring frontier academic knowledge to teachers and students and boost its international competitiveness and influence.

\section{References}

Bradford, H., Guzmán, A., \& Trujillo, M. A. (2017). Determinants of successful internationalisation processes in business schools. Journal of Higher Education Policy and Management, 39(4), 435-452. https://doi.org/10.1080/1360080X.2017.1330798

Chen, X. F. (2002). The Internationalization of Higher Education: A Cross-century Trend (pp. 11-15). Fuzhou: Fujian Education Press.

Czinkota, M. R., Grossman, D. A., Javalgi, R. R. G., \& Nugent, N. (2009). Foreign Market Entry Model of Service Firms: The case of US MBA programs. Journal of World Business, 44, 274-286. https://doi.org/10.1016/j.jwb.2008.08.002

Freitas, M. E. D., Bertero, C. O., Fleury, M. T. L., Fabio, L. M., \& Andre, L. S. (2016). Process of Internationalization of Business Schools in Latin America: The case of EAESP/FGV, Brazil. Tertiary Education \& Management, 1-20. https://doi.org/10.1080/13583883.2016.1222630

Gao, J. M. (1994). On the Internationalization of China's Business Education. Shaanxi Journal of Business Administration, 3, 81-87.

Gu, M. Y. (1998). Dictionary of Education. Shanghai: Shanghai Education Press.

Guillotin, B., \& Mangematin, V. (2015). Internationalization strategies of business schools: how flat is the world?. Thunderbird International Business Review, 57(5), 343-357. https://doi.org/10.1002/tie.21705

Hou, G. L., \& Zou, Z. (2016). Research Report of Internationalization of Graduate Education-Take Institute of Technology as an Example. Science Innovation, 4(6), 253. https://doi.org/10.11648/j.si.20160406.12

Hujuk, J. (2015). Study Abroad Programs as Tools of Internationalization: Which Factors Influence Hungarian Business Students to Participate?. Journal of Teaching in International Business, 26(1), 56-76. https://doi.org/10.1080/08975930.2014.956973

Javalgi, R. R. G., \& Grossman, D. A. (2014). Firm Resources and Host-country Factors Impacting Internationalization of Knowledge-intensive Service Firms. Thunderbird International Business Review, 56, 285-300. https://doi.org/10.1002/tie.21622 
Knight, J. (1994). Internationalization: Elements and Checkpoints. Canadian Bureau for International Education. Ottawa.

Liu, S. B., Zhou, J. X., Zhang, Y., \& Song, H. M. (2015). Challenges Faced by Business School Quality Management and Construction Approaches. Human Resource Management, 10, 133-136.

McCormick, M., \& Stephen, S. A. K. (2016). Exploring the Effectiveness of the Internationalization of Business Education at the Undergraduate Level. Journal of International Business Education, 11, 49-64.

Niu, H. Y., Luan, S., \& Song, Y. (2019). Performance Evaluation of Internationalization of Business Education. Scientific Research Management, 4, 277-287.

Niu, H. Y., Sun, J., Song, Y., \& Zhou, Z. B. (2017). A Comparative Study on the Internationalization of Business Education in Colleges and Universities. Business Studies, 24(6), 15-23.

Seno-Alday, S., \& Budde-Sung, A. (2016). Closing the learning loop: A review of assignments in international business education. Journal of Teaching in International Business, 27(2-3), 68-87. https://doi.org/10.1080/08975930.2016.1208783

Van der Wende, M. (1997). Missing Links: The Relationship between National policies for Internationalization and those for Higher Education in Europe. Stockholm: Hegskoeverket studies, National Agency for Higher Education.

Wang, Y. S. (2002). The Scientific Connotation of the Internationalization of Higher Education. Modern University Education, 1, 5-8.

Wu, Y. (2018). The New Engineering: The Future of Higher Education of Engineering-strategic thinking on the future of higher education. Research in Higher Education of Engineering, 6, 1-3.

Yao, Y. H. (2019). Internationalization of Higher Education: Conceptual Framework, Practice Exploration and Development Path. Higher Education of Sciences, 2, 9-18.

Zha, Q. (2003). International of Higher Education: towards a conceptual framework. Policy Futures in Education, 1(2), 248-270. https://doi.org/10.2304/pfie.2003.1.2.5

Zheng, B. (1997). The Internationalization of Education and the Culture of Post-Development Countries. Teaching and Research, 9, 50-53.

Zhu, J. M., Lin, M. Q., Li, C. F., \& Han, T. T. (2017). The Path of First-Class Discipline Construction based on the Concept of Education Certification. China Higher Education, 15, 53-55.

\section{Copyrights}

Copyright for this article is retained by the author(s), with first publication rights granted to the journal.

This is an open-access article distributed under the terms and conditions of the Creative Commons Attribution license (http://creativecommons.org/licenses/by/4.0/). 